\title{
Regulation of the $\mathrm{Ca}_{\mathrm{v}} 3.2$ calcium channels in health and disease Regulácia $\mathrm{Ca}_{\mathrm{v}} 3.2$ vápnikových kanálov v zdraví a chorobe
}

${ }^{1}$ Slovak Academy of Sciences, Centre of Bioscience, Bratislava, Slovak Republic

2University of Ss. Cyril and Methodius in Trnava, Faculty of Natural Sciences, Trnava, Slovak Republic
${ }^{1}$ Slovenská akadémia vied, Biomedicínske centrum SAV,

Bratislava, Slovenská Republika

${ }^{2}$ Univerzita sv. Cyrila a Metoda v Trnave,

Fakulta prírodných vied, Trnava, Slovenská Republika

Received 24 October, 2016, accepted 16 March, 2017

\begin{abstract}
Family of T-type or low-voltage activated calcium channels consists of three members: $\mathrm{Ca}_{\mathrm{v}} 3.1, \mathrm{Ca}_{\mathrm{v}} 3.2$, and $\mathrm{Ca}_{v} 3.3$. Ca 3.2 channel has almost identical biophysical properties as the $\mathrm{Ca}_{\mathrm{v}} 3.1$ channel, but is distinguished by a specific tissue expression profile and a prominent role in several pathologies, including neuropathic pain, epilepsy, and dysregulation of cardiac rhythm. Further, it may be involved in phenotype of autism spectrum disorders, and amyotrophic lateral sclerosis. It represents a promising target for future pharmacotherapies.

Slovak Skupina nízkonapätových vápnikových kanálov nazývaných aj kanály T-typu má troch členov: Ca 3.1, Ca 3.2, a Ca 3.3. Ca 3.2 abstract kanál má temer identické biofyzikálne vlastnosti ako Ca 3.1 kanál, ale líši sa od neho tým, že je exprimovaný v iných tkanivách a má dôležitú úlohu pri viacerých závažných ochoreniach ako sú neuropatická bolest', epilepsia a poruchy regulácie srdcového rytmu. Preto tento kanál môže byt' ciel’om nových liečiv.
\end{abstract}

Keywords T-type calcium channel-Ca 3.2 -regulation-trafficking-glycosylation

Klúčové vápnikové kanály T-typu-regulácia Ca 3.2 kanála - transport do membrány-glykozylácia

slová:

\section{INTRODUCTION}

T-type calcium channels, also known as low-voltage-activated calcium channels, or $\mathrm{Ca}_{\mathrm{v}} 3$ channels, are characterised by a relatively negative voltage activation threshold around $-60 \mathrm{mV}$. Thisfeatureenables them to operatenear the resting membrane potential of most electrically excitable cells and contribute to the initiation of an action potential. T-type calcium channels play a fundamental role in shaping neuronal excitability, as they generate the so-called low threshold calcium action potential in neurons lacking sodium channels and support burst firing (Perez-Reyes, 2003). In the heart, they contribute to the pacemaker function of sinoatrial nodal cells. Three subtypes of $\mathrm{Ca}_{\mathrm{v}} 3$ channels are currently known: $\mathrm{Ca}_{\mathrm{v}} 3.1, \mathrm{Ca}_{\mathrm{v}} 3.2$ and $\mathrm{Ca}_{v} 3.3$, with $\mathrm{a}_{1}$ subunits encoded by CACNA1G, CACNA1H, and CACNA1l genes (Lacinova et al., 2000) 2000. Ca 3.1 and $\mathrm{Ca}_{\mathrm{v}} 3.2$ channels share the basic biophysical properties, for example, kinetics of activation and inactivation (Figure $1 \mathrm{~A}$ ), voltage dependence of activation and inactivation (Figure $1 \mathrm{~B}$ ), and kinetics of recovery from an inactivation (Lacinova, 2005). $\mathrm{Ca}_{\mathrm{v}} 3.3$ channels have distinguished biophysical properties (Chemin et al., 2002) having one decimal order slower activation and inactivation kinetics (Figure $1 \mathrm{~A}$ ), but virtually identical voltage dependence of activation (Figure $1 \mathrm{~B}$ ) compared to the $\mathrm{Ca}_{\mathrm{v}} 3.1$ and $\mathrm{Ca}_{\mathrm{v}} 3.2$ channels. These channels are expressed almost exclusively in the brain (Monteil et al., 2000). Ca 3.1 and Ca 3.2 channels are ubiquitously expressed; nevertheless, their expression patterns only partly overlap in the mammalian brain (Lacinova, 2004; Aguado et al., 2016) and throughout the mammalian body at large. In addition to neuronal tissue, Ca 3.2 was identified in the heart (Cribbs et al., 1998), skeletal muscle (Berthier et al., 2002), pancreas (Braun et al., 2008), kidney (Hayashi et al., 2007), and also in female (Ohkubo et al., 2005), and male reproductive tissues (Darszon et al., 2006). 

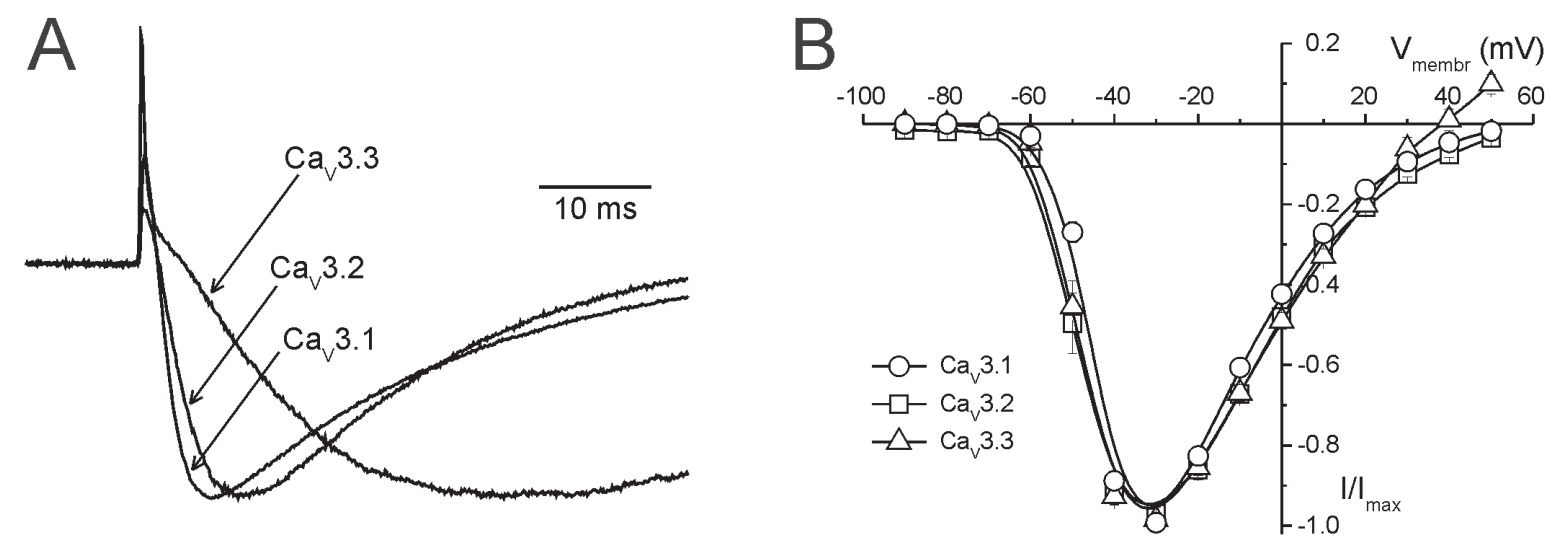

Figure 1. Basic biophysical profile of T-type calcium channels. a. Examples of current traces activated by a rectangular depolarising pulse from a potential of - $100 \mathrm{mV}$ to a -20 $\mathrm{mV}$. Traces corresponding to individual channel subtypes $(\mathrm{Ca}, 3.1, \mathrm{Ca} 3.2$, and $\mathrm{Ca}$ 3.3) are marked. b. Current-voltage relations for all three subtypes (Ca 3.1, Ca 3.2, and $\mathrm{Ca}$ 3.3) of T-type calcium channel, as marked.

The altered function of T-type calcium channels was implied in several pathological states. Ca 3.2 channels seem to be of a particular importance as they were implied in several heritable diseases.

\section{CA 3.2 CHANNELS IN NEURONS}

Typical resting membrane potential of most neurons corresponds to a voltage range at which T-type calcium channels are partly inactivated. Minor hyperpolarisation recruits additional T-type calcium channels, enhances T-type calcium current and enables the generation of low-threshold action potentials. Low-threshold action potentials form the backbone for neuronal burst firing (Huguenard, 1998). Ability of $\mathrm{Ca}_{\mathrm{v}} 3$ channels to initiate an action potential firing may contribute to epileptiform activity. Indeed, mutations in $\mathrm{Ca}_{\mathrm{v}} 3.2$ channel were associated with the childhood absence epilepsy (Chen et al., 2003) and with other forms of idiopathic generalised epilepsy (Heron et al., 2004; Heron et al., 2007). Identified mutations were either gain-of-function or did not alter electrophysiological properties of the channel. Mechanism by which these mutations increase neuronal excitability, and subsequently increase seizure susceptibility, was investigated (Eckle et al., 2014). These authors suggested that increased current density caused by an epilepsy mutation C456S may be at least partly due to the increased surface expression of $\mathrm{Ca}_{\mathrm{v}} 3.2$ channels. Further, this mutation enhanced glutamatergic transmission by the enhancement of local calcium influx at synapses (Wang et al., 2015). It is interesting that in spite of that, $\mathrm{Ca}_{\mathrm{v}} 3.1$ channel has the same electrophysiological profile as $\mathrm{Ca}_{\mathrm{v}} 3.2$ channel, $\mathrm{Ca}_{\mathrm{v}} 3.1^{-1 /}$ mice are resistant to baclofen-induced epilepsy (Kim et al., 2001), and overexpression of $\mathrm{Ca}_{\mathrm{v}} 3.1$ channel induced absence epilepsy in mice (Ernst et al., 2009), no consistent linkage of this channel to epilepsy was found until now.

Autism spectrum disorders (ASD) represent complex neurodevelopmental conditions. Causes of ASD remain a mystery, however, heritable components were demonstrated (Zoghbi, 2003). Interestingly, mutations in voltage-dependent calcium channels associated with ASD were reported. Initially, the gain-of-function mutation of $\mathrm{Ca}_{\mathrm{v}} 1.2 \mathrm{~L}$-type calcium channel was described by Splawski and coauthors (Splawski et al., 2004; Splawski et al., 2005). Soon, a group led by the same authors reported four loss-of-function point mutations in $\mathrm{Ca}_{\mathrm{v}} 3.2$ channel, associated with ASD (Splawski et al., 2006). How an altered conductance of $\mathrm{Ca}_{\mathrm{v}} 3.2$ channels arising from these mutations may lead to ASD phenotype remains unknown.

Two rare recessive variants of the CACNA1 H gene associated with sporadic amyotrophic lateral sclerosis (ALS) were recently discovered (Steinberg et al., 2015). When these missense mutations (V1689M and A1705T) were introduced into recombinant channels and expressed, they produced moderate but significant changes in the channel properties consistent with loss-of-function of the mutated channel (Rzhepetskyy et al., 2016). Mathematical modelling suggested that these changes may result in decreased excitability of thalamic neurons (Rzhepetskyy et al., 2016).

Keyrole of neuronallyexpressed Ca 3 3.2 channels in nociception was established (Todorovic and Jevtovic-Todorovic, 2013). Downregulation of these channels in rat dorsal root ganglion neurons resulted in major antinociceptive, anti-hyperalgesic, and anti-allodynic effects (Bourinet et al., 2005). Inhibition of $\mathrm{Ca}_{\mathrm{v}} 3.2$ channels contributed to antinociceptive effect of epipregnanolone (Ayoola et al., 2014), KYS-05090S (M'Dahoma et al., 2016), and to the peripheral anti-nociceptive effect of substance $P$ (Huang et al., 2016). Ca 3.2 channel emerged as a prospective target of future analgesics.

\section{CA 3.2 CHANNELS IN THE CARDIOVASCULAR SYSTEM}

$\mathrm{Ca}_{\mathrm{v}} 3.2$ channel gene CACNA1H was originally cloned from a human heart by a screening of cDNA library with the $\mathrm{Ca}_{\mathrm{v}} 3.1$ gene (Cribbs et al., 1998). These channels are expressed in 


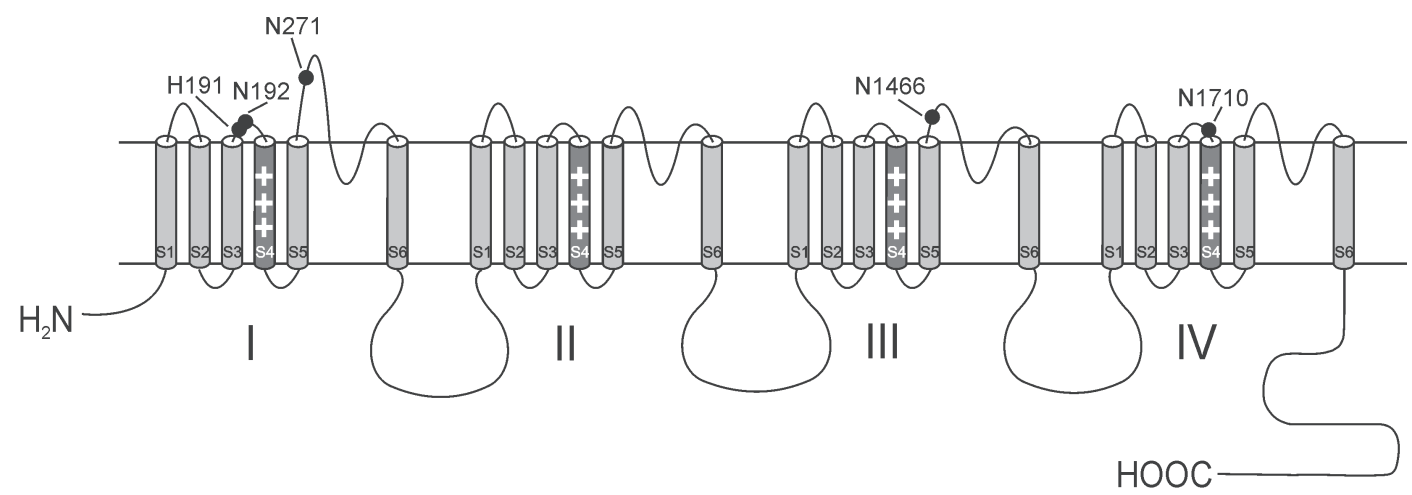

Figure 2. Scheme of T-type a1 subunit. a1 subunit of T-type calcium channel consists of four homological domains (I - IV). Each domain consists of six transmembrane segments S1-S6. S4 segment contains 5-6 positively charged amino acids and is responsible for voltage sensing. Segments S5-S6 create conducting pore of the channel. Location of histidine 191 (H191) and four extracellularly located asparagines (N192, N271, N1466, and N1710) are marked by filled circles.

ventricular myocytes, where they mediate chronotropic action of corticosteroids (Maturana et al., 2009) and aldosterone (Lalevee et al., 2005). In sinoatrial nodal cells, $\mathrm{Ca}_{\mathrm{v}} 3.2$ channels contribute to cardiac pacemaking due to their ability to be activated during initial slow depolarising phase of sinoatrial action potential, which enables them to contribute to this depolarisation process (Husse and Franz, 2016). Their expression in sinoatrial cells is increased in streptozotocin-induced diabetic rats (Ferdous et al., 2016) and thus, they may contribute to cardiac-related comorbidity in diabetic patients. Recently, gain-of-function mutation CACNA1H(M1549V) of the Ca 3.2 channel was identified, which results in an early onset hypertension caused by increased aldosterone production (Scholl et al., 2015).

\section{REGULATION OF CA 3.2 CHANNELS BY GASOTRANSMITTERS}

Gasotransmitters, such as nitric oxide, carbon monoxide and hydrogen sulphide may act as calcium channel modulators. In recent years, (patho)physiological importance of $\mathrm{H}_{2} \mathrm{~S}$ is being acknowledged (Li et al., 2011). Acutely applied micromolar $\mathrm{H}_{2} \mathrm{~S}$ inhibited the current through the recombinant $\mathrm{Ca}_{\mathrm{v}} 3.2$ channel, but not through $\mathrm{Ca}_{\mathrm{v}} 3.1$ or $\mathrm{Ca}_{\mathrm{v}} 3.3$ channels (Elies et al., 2014). It was shown that $\mathrm{H}_{2} \mathrm{~S}$ interacts with the $\mathrm{Ca}_{\mathrm{v}} 3.2$ channel at an amino acid histidine in a position 191 (H191, Figure 2), which is absent in $\mathrm{Ca}_{\mathrm{v}} 3.1$ and $\mathrm{Ca}_{\mathrm{v}} 3.3$ channels (Elies et al., 2015). The same amino acid residue is responsible for channel inhibition by $\mathrm{Zn}^{2+}$ (Nelson et al., 2007), by $\mathrm{Ni}^{2+}$ (Kang et al., 2006), and for redox regulation of the channel. Elies and coauthors suggested that $\mathrm{H}_{2} \mathrm{~S}$ may enhance channel sensitivity to $\mathrm{Zn}^{2+}$ ions (Elies et al., 2016). However, chronic exposure to millimolar $\mathrm{H}_{2} \mathrm{~S}$ enhanced T-type calcium current in NG108-15 cells and evoked hyperalgesia in rats (Kawabata et al., 2007). Acute augmentation of the current through recombinant $\mathrm{Ca}_{\mathrm{v}} 3.2$, but not $\mathrm{Ca}_{\mathrm{v}} 3.1$ channel was also achieved by millimolar $\mathrm{H}_{2} \mathrm{~S}$ (Elies et al., 2014). Mechanism of this dual effect remains unknown.
Carbon monoxide inhibited all three recombinant $\mathrm{Ca}_{\mathrm{v}} 3$ channels and reached half-maximal inhibition in concentration around $3 \mu \mathrm{M}$ (Boycott et al., 2013). The effect of nitric monoxide on T-type calcium channels was not investigated.

\section{REGULATION OF CA 3.2 CHANNELS BY OTHER ENDOGENOUS MOLECULES}

T-type channels are also sensitive to a number of endogenous agents. For instance, arachidonic acid potently shifts the steady-state inactivation of $\mathrm{Ca}_{\mathrm{v}} 3.2$ channels by -25 $\mathrm{mV}$, eliminating the window current (Zhang et al., 2000). Considering that arachidonic acid is used in a number of anabolic bodybuilding supplements, the alteration of immune response may represent a side effect of these products. Endogenous cannabinoid anandamide inhibits all three $\mathrm{Ca}_{\mathrm{v}} 3$ channels with order of efficiency $\mathrm{Ca}_{\mathrm{v}} 3.2>\mathrm{Ca}_{\mathrm{v}} 3.3$ $>\mathrm{Ca}_{\mathrm{v}} 3.1$ (Chemin et al., 2001). Inhibition of $\mathrm{Ca}_{\mathrm{v}} 3.2$ channels by endocannabinoid N-arachidonoyl dopamine (Ross et al., 2009), by endogenous lipoamino acids (Barbara et al., 2009), and by $\mathrm{N}$-arachidonoyl serotonin (Gilmore et al., 2012) may contribute to their anti-nociceptive effect attributed to the interaction with TRPV1 channel.

\section{REGULATION OF CA 3.2 CHANNELS BY GLUCOSE}

Glycosylation represents one of the most prevalent mechanisms of post-translational modification of proteins (Moremen et al., 2012). It is reversible and proteins can undergo dynamic glycosylation and deglycosylation. Asparagine (N)-linked glycosylation of various voltage- and ligand-gated channels (Ufret-Vincenty et al., 2001; Watanabe et al., 2003; Cohen, 2006) including Ca 3.2 channel (Weiss et al., 2013) was documented. Consensus $\mathrm{N}$-linked glycosylation site has an amino acid sequence $\mathrm{N}-X-\mathrm{S} / \mathrm{T}$. Four corresponding asparagines are located in the extracellular loops of the $\mathrm{Ca}_{\mathrm{v}} 3.2$ channel: N192, N271, N1466 and N1710 (Figure 2). Inhibition of $\mathrm{N}$-linked glycosylation by tunicamycin reduced an expression 
of the Ca 3.2 channel in cell membrane (Weiss et al., 2013) and reduced the current density. Increase of extracellular glucose concentration from $5 \mathrm{mM}$ (physiological level) to 25 $\mathrm{mM}$ (corresponding to clinically observed hyperglycaemia) potentiated the trafficking of channel protein to the plasma membrane (Lazniewska et al., 2016) and increased the current density (Weiss et al., 2013). An uneven role of glycosylation of individual asparagines was demonstrated by a substitution of each asparagine by glutamine. Mutations N271Q and N1710Q disrupted the channel expression and no detectable current was observed in cells transfected with these constructs (Weiss et al., 2013; Ondacova et al., 2016). Total protein expression of N192Q and N1466Q channels was unaffected but their trafficking to the surface membrane was decreased (Weiss et al., 2013). Glycosylation could regulate the current amplitude solely by altering the number of functional channel expressed in the plasma membrane. Alternatively, changes in channel gating could contribute to decreased current amplitude. To test for involved mechanisms, the charge movement in wild type and mutant channels was investigated by Ondacova and coauthors. The charge movement arises from upwards movement of $\mathrm{S} 4$ segments in all four channel domains (Figure 2) and is proportional to the number of functional channels in a cell membrane. Ratio maximal current/maximal charge movement is proportional to the channel opening probability (Agler et al., 2005). Individual mutations (N192Q or N1466Q) did not alter this ratio significantly. However, when both asparagines were replaced by glutamines, the ratio maximal current/maximal charge movement decreased significantly, suggesting that proper glycosylation of the $\mathrm{Ca}_{\mathrm{v}} 3.2$ channel may also upregulate the channel's opening probability (Ondacova et al., 2016). Considering that the elevated glucose caused the enhanced activity of $\mathrm{Ca}_{\mathrm{v}} 3.2$ channels, which plays an important role in the peripheral nociception, this mechanism may be involved in the genesis of diabetic neuropathy. Therefore, these channels are emerging targets for its therapy (Orestes et al., 2013).

\section{REGULATION OF THE CA 3.2 CHANNELS BY PHOSPHORYLATION}

$\mathrm{Ca}_{\mathrm{v}} 3.2$ channels are regulated by multiple phosphorylation mechanisms. Using high resolution mass spectroscopy, 34 putative phosphorylation sites, represented by serine and threonine residues, were identified in the intracellular loops of the rat $\mathrm{Ca}_{\mathrm{v}} 3.2$ channel and 43 such sites were identified in the human $\mathrm{Ca}_{\mathrm{v}} 3.2$ channel (Blesneac et al., 2015). Dephosphorylation of the channel by non-specific phosphatase AP accelerated its activation and inactivation kinetics, and shifted the voltage dependencies of channel activation and inactivation in hyperpolarising direction
(Blesneac et al., 2015). Several of these phosphorylation sites were described previously. S1198 in the cytoplasmic loop, connecting the channel domains II and III, is phosphorylated by CaMKII (Welsby et al., 2003; Yao et al., 2006). This amino acid residue is unique to the CACNA1H sequence (PerezReyes, 2003). Its phosphorylation potentiates calcium entry through the $\mathrm{Ca}_{\mathrm{v}} 3.2$ channels by shifting the half-maximal activation voltage towards the more negative membrane potentials and by increasing voltage sensitivity of the channel (Welsby et al., 2003). Phosphorylation of S1107 located in the same intracellular loop by protein kinase $A$ is necessary for channel inhibition by $\mathrm{G} \beta \gamma$ dimers (Hu et al., 2009). This signalling pathway is specific for the $\mathrm{Ca}_{\mathrm{v}} 3.2$ channel and may be a mechanism mediating dopamine inhibition of this channel (Hu et al., 2009).

Vast majority of experiments are conducted at a room temperature. Chemin and coauthors demonstrated that protein kinases $A$ and $C$, but not $G$, can enhance the current through all three $\mathrm{Ca}_{\mathrm{v}} 3$ channel subtypes at a physiological temperature $\left(30-37^{\circ} \mathrm{C}\right)$, while no effect was observed at room temperature $\left(20-27^{\circ} \mathrm{C}\right.$ ) (Chemin et al., 2007). This observation should be taken into account when we think about regulation of T-type calcium current in a mammalian organism.

\section{REGULATION OF THE CA $\mathrm{v}^{3.2}$ CHANNELS BY UBIQUITINATION}

Ubiquitination is a common enzymatic post-translational modification of proteins occurring in eukaryotic cells. $\mathrm{Ca}_{\mathrm{v}} 3.2$ channels are under control by ubiquitinating and deubiquitinating enzymes as well (Zamponi et al., 2015). Deubiquitination of the $\mathrm{Ca}_{\mathrm{v}} 3.2$ channel by deubiquitinase USP5 results in an increased T-type calcium current that is responsible for inflammatory and neuropathic pain (Gadotti et al., 2015). Disrupting USP5/Ca 3.2 channel interactions prevented such pain and represents a concept for a new class of analgesics (Garcia-Caballero et al., 2014; Gadotti et al., 2015; Garcia-Caballero et al., 2016).

\section{CONCLUSION}

$\mathrm{Ca}_{\mathrm{v}} 3.2$ channels play a unique role in nociception, in heart automaticity, in several types of epilepsy and convulsion. They may be involved in diabetic neuropathy, autism spectrum disorders, or amyotrophic lateral sclerosis. These features make them valuable pharmacological targets.

\section{ACKNOWLEDGEMENT}

While working on this manuscript, LL was supported by VEGA 2/0107/16 grant. 
[1] Agler HL, Evans J, Tay LH, Anderson MJ, Colecraft HM, Yue DT. G protein-gated inhibitory module of $\mathrm{N}$-type $\left(\mathrm{Ca}_{v} 2.2\right) \mathrm{Ca}^{2+}$ channels. Neuron. 2005; 46:891-904.

[2] Aguado C, Garcia-Madrona S, Gil-Minguez M, Lujan R. Ontogenic Changes and Differential Localization of T-type $\mathrm{Ca}(2+)$ Channel Subunits Cav3.1 and Cav3.2 in Mouse Hippocampus and Cerebellum. Front Neuroanat. 2016; 10:83.

[3] Ayoola C, Hwang SM, Hong SJ, Rose KE, Boyd C, Bozic N, Park JY, Osuru HP, DiGruccio MR, Covey DF, Jevtovic-Todorovic V, Todorovic SM. Inhibition of CaV3.2 T-type calcium channels in peripheral sensory neurons contributes to analgesic properties of epipregnanolone. Psychopharmacology (Berl). 2014; 231:350315.

[4] Barbara G, Alloui A, Nargeot J, Lory P, Eschalier A, Bourinet $\mathrm{E}$, Chemin J. T-type calcium channel inhibition underlies the analgesic effects of the endogenous lipoamino acids. J Neurosci. 2009; 29:13106-14.

[5] Berthier C, Monteil A, Lory P, Strube C. Alpha(1H) mRNA in single skeletal muscle fibres accounts for T-type calcium current transient expression during fetal development in mice. J Physiol. 2002; 539:681-91.

[6] Blesneac I, Chemin J, Bidaud I, Huc-Brandt S, Vandermoere F, Lory P. Phosphorylation of the Cav3.2 T-type calcium channel directly regulates its gating properties. Proc Natl Acad Sci U S A. 2015; 112:13705-10.

[7] Bourinet E, Alloui A, Monteil A, Barrere C, Couette B, Poirot O, Pages A, McRory J, Snutch TP, Eschalier A, Nargeot J. Silencing of the Cav3.2 T-type calcium channel gene in sensory neurons demonstrates its major role in nociception. EMBO J. 2005; 24:315-24.

[8] Boycott HE, Dallas ML, Elies J, Pettinger L, Boyle JP, Scragg JL, Gamper N, Peers C. Carbon monoxide inhibition of Cav3.2 T-type $\mathrm{Ca} 2+$ channels reveals tonic modulation by thioredoxin. FASEB J. 2013; 27:3395-407.

[9] Braun M, Ramracheya R, Bengtsson M, Zhang Q, Karanauskaite J, Partridge C, Johnson PR, Rorsman P. Voltage-gated ion channels in human pancreatic beta-cells: electrophysiological characterization and role in insulin secretion. Diabetes. 2008; 57:1618-28.

[10] Cohen DM. Regulation of TRP channels by N-linked glycosylation. Semin Cell Dev Biol. 2006; 17:630-7.

[11] Cribbs LL, Lee JH, Yang J, Satin J, Zhang Y, Daud A, Barclay J, Williamson MP, Fox M, Rees M, Perez-Reyes E. Cloning and characterization of $\mathrm{a}_{1 \mathrm{H}}$ from human heart, a member of the T-type $\mathrm{Ca}^{2+}$ channel gene family. Circ Res. 1998; 83:103-9.

[12] Darszon A, Lopez-Martinez P, Acevedo JJ, Hernandez-Cruz A, Trevino CL. T-type Ca2+ channels in sperm function. Cell Calcium. 2006; 40:241-52.

[13] Eckle VS, Shcheglovitov A, Vitko I, Dey D, Yap CC, Winckler B, Perez-Reyes E. Mechanisms by which a CACNA1H mutation in epilepsy patients increases seizure susceptibility. J Physiol. 2014; 592:795-809.
[14] Elies J, Scragg JL, Boyle JP, Gamper N, Peers C. Regulation of the T-type $\mathrm{Ca}(2+)$ channel Cav3.2 by hydrogen sulfide: emerging controversies concerning the role of $\mathrm{H} 2 \mathrm{~S}$ in nociception. J Physiol. 2016; 594:4119-29.

[15] Elies J, Scragg JL, Dallas ML, Huang D, Huang S, Boyle JP, Gamper $\mathrm{N}$, Peers C. Inhibition of T-type Ca2+ Channels by Hydrogen Sulfide. Adv Exp Med Biol. 2015; 860:353-60.

[16] Elies J, Scragg JL, Huang S, Dallas ML, Huang D, MacDougall D, Boyle JP, Gamper N, Peers C. Hydrogen sulfide inhibits Cav3.2 T-type Ca2+ channels. FASEB J. 2014; 28:5376-87.

[17] Ernst WL, Zhang Y, Yoo JW, Ernst SJ, Noebels JL. Genetic enhancement of thalamocortical network activity by elevating alpha 1g-mediated low-voltage-activated calcium current induces pure absence epilepsy. J Neurosci. 2009; 29:1615-25.

[18] Ferdous Z, Qureshi MA, Jayaprakash P, Parekh K, John A, Oz M, Raza H, Dobrzynski H, Adrian TE, Howarth FC. Different Profile of mRNA Expression in Sinoatrial Node from StreptozotocinInduced Diabetic Rat. PLoS One. 2016; 11:e0153934.

[19] Gadotti VM, Caballero AG, Berger ND, Gladding CM, Chen L, Pfeifer TA, Zamponi GW. Small organic molecule disruptors of Cav3.2 - USP5 interactions reverse inflammatory and neuropathic pain. Mol Pain. 2015; 11:12.

[20] Garcia-Caballero A, Gadotti VM, Chen L, Zamponi GW. A cellpermeant peptide corresponding to the CUBP domain of USP5 reverses inflammatory and neuropathic pain. Mol Pain. 2016; 12.

[21] Garcia-Caballero A, Gadotti VM, Stemkowski P, Weiss N, Souza IA, Hodgkinson V, Bladen C, Chen L, Hamid J, Pizzoccaro A, Deage $M$, Francois A, Bourinet $E$, Zamponi GW. The deubiquitinating enzyme USP 5 modulates neuropathic and inflammatory pain by enhancing Cav3.2 channel activity. Neuron. 2014; 83:1144-58.

[22] Gilmore AJ, Heblinski M, Reynolds A, Kassiou M, Connor M. Inhibition of human recombinant T-type calcium channels by N-arachidonoyl 5-HT. Br J Pharmacol. 2012; 167:1076-88.

[23] Hayashi K, Wakino S, Sugano N, Ozawa Y, Homma K, Saruta T. $\mathrm{Ca} 2+$ channel subtypes and pharmacology in the kidney. Circ Res. 2007; 100:342-53.

[24] Heron SE, Khosravani H, Varela D, Bladen C, Williams TC, Newman MR, Scheffer IE, Berkovic SF, Mulley JC, Zamponi GW. Extended spectrum of idiopathic generalized epilepsies associated with CACNA1H functional variants. Ann Neurol. 2007; 62:560-8.

[25] Heron SE, Phillips HA, Mulley JC, Mazarib A, Neufeld MY, Berkovic SF, Scheffer IE. Genetic variation of CACNA1H in idiopathic generalized epilepsy. Ann Neurol. 2004; 55:595-6.

[26] Hu C, Depuy SD, Yao J, McIntire WE, Barrett PQ. Protein kinase A activity controls the regulation of T-type CaV3.2 channels by Gbetagamma dimers. J Biol Chem. 2009; 284:7465-73.

[27] Huang D, Huang S, Gao H, Liu Y, Qi J, Chen P, Wang C, Scragg JL, Vakurov A, Peers C, Du X, Zhang H, Gamper N. Redox-Dependent Modulation of T-Type $\mathrm{Ca}(2+)$ Channels in Sensory Neurons Contributes to Acute Anti-Nociceptive Effect of Substance P. Antioxid Redox Signal. 2016; 25:233-51. 
[28] Huguenard JR. Low-voltage-activated (T-type) calcium-channel genes identified. Trends Neurosci. 1998; 21:451-2.

[29] Husse B, Franz WM. Generation of cardiac pacemaker cells by programming and differentiation. Biochim Biophys Acta. 2016; 1863:1948-52.

[30] Chemin J, Mezghrani A, Bidaud I, Dupasquier S, Marger F, Barrere C, Nargeot J, Lory P. Temperature-dependent modulation of CaV3 T-type calcium channels by protein kinases $\mathrm{C}$ and $\mathrm{A}$ in mammalian cells. J Biol Chem. 2007; 282:32710-8.

[31] Chemin J, Monteil A, Perez-Reyes E, Bourinet E, Nargeot J, Lory P. Specific contribution of human T-type calcium channel isotypes (alpha(1G), alpha(1H) and alpha(1l)) to neuronal excitability. J Physiol. 2002; 540:3-14.

[32] Chemin J, Monteil A, Perez-Reyes E, Nargeot J, Lory P. Direct inhibition of T-type calcium channels by the endogenous cannabinoid anandamide. EMBO J. 2001; 20:7033-40.

[33] Chen Y, Lu J, Pan H, Zhang Y, Wu H, Xu K, Liu X, Jiang Y, Bao X, Yao Z, Ding K, Lo WH, Qiang B, Chan P, Shen Y, Wu X. Association between genetic variation of $\mathrm{CACNA} 1 \mathrm{H}$ and childhood absence epilepsy. Ann Neurol. 2003; 54:239-43.

[34] Kang HW, Park JY, Jeong SW, Kim JA, Moon HJ, Perez-Reyes E, Lee $\mathrm{JH}$. A molecular determinant of nickel inhibition in $\mathrm{Ca}_{\mathrm{v}} 3.2 \mathrm{~T}$-type calcium channels. J Biol Chem. 2006; 281:4823-30.

[35] Kawabata A, Ishiki T, Nagasawa K, Yoshida S, Maeda Y, Takahashi T, Sekiguchi F, Wada T, Ichida S, Nishikawa H. Hydrogen sulfide as a novel nociceptive messenger. Pain. 2007; 132:74-81.

[36] Kim D, Song I, Keum S, Lee T, Jeong MJ, Kim SS, McEnery MW, Shin HS. Lack of the burst firing of thalamocortical relay neurons and resistance to absence seizures in mice lacking $\mathrm{a}_{1 \mathrm{G}} \mathrm{T}_{\text {-type } \mathrm{Ca}^{2+}}$ channels. Neuron. 2001; 31:35-45.

[37] Lacinova L. Pharmacology of recombinant low-voltage activated calcium channels. Curr Drug Targets CNS Neurol Disord. 2004; 3:105-11.

[38] Lacinova L. Voltage-dependent calcium channels. Gen Physiol Biophys. 2005; 24 Suppl 1:1-78.

[39] Lacinova L, Klugbauer N, Hofmann F. Low voltage activated calcium channels: from genes to function. Gen Physiol Biophys. 2000; 19:121-36.

[40] Lalevee N, Rebsamen MC, Barrere-Lemaire S, Perrier E, Nargeot J, Benitah JP, Rossier MF. Aldosterone increases T-type calcium channel expression and in vitro beating frequency in neonatal rat cardiomyocytes. Cardiovasc Res. 2005; 67:216-24.

[41] Lazniewska J, Rzhepetskyy Y, Zhang FX, Zamponi GW, Weiss N. Cooperative roles of glucose and asparagine-linked glycosylation in T-type calcium channel expression. Pflugers Arch. 2016.

[42] Li L, Rose P, Moore PK. Hydrogen sulfide and cell signaling. Annu Rev Pharmacol Toxicol. 2011; 51:169-87.

[43] M'Dahoma S, Gadotti VM, Zhang FX, Park B, Nam JH, Onnis V, Balboni G, Lee JY, Zamponi GW. Effect of the T-type channel blocker KYS-05090S in mouse models of acute and neuropathic pain. Pflugers Arch. 2016; 468:193-9.

[44] Maturana A, Lenglet S, Python M, Kuroda S, Rossier MF. Role of the T-type calcium channel CaV3.2 in the chronotropic action of corticosteroids in isolated rat ventricular myocytes. Endocrinology. 2009; 150:3726-34.
[45] Monteil A, Chemin J, Leuranguer V, Altier C, Mennessier G, Bourinet E, Lory P, Nargeot J. Specific properties of T-type calcium channels generated by the human $\mathrm{a}_{11}$ subunit. J Biol Chem. 2000; 275:16530-5.

[46] Moremen KW, Tiemeyer M, Nairn AV. Vertebrate protein glycosylation: diversity, synthesis and function. Nat Rev Mol Cell Biol. 2012; 13:448-62.

[47] Nelson MT, Woo J, Kang HW, Vitko I, Barrett PQ, Perez-Reyes E, Lee JH, Shin HS, Todorovic SM. Reducing agents sensitize C-type nociceptors by relieving high-affinity zinc inhibition of T-type calcium channels. Journal of Neuroscience. 2007; 27:8250-8260.

[48] Ohkubo T, Inoue Y, Kawarabayashi T, Kitamura K. Identification and electrophysiological characteristics of isoforms of T-type calcium channel $\mathrm{Ca}(\mathrm{v}) 3.2$ expressed in pregnant human uterus. Cell Physiol Biochem. 2005; 16:245-54.

[49] Ondacova K, Karmazinova M, Lazniewska J, Weiss N, Lacinova L. Modulation of Cav3.2 T-type calcium channel permeability by asparagine-linked glycosylation. Channels (Austin). 2016; 10:17584.

[50] Orestes P, Osuru HP, McIntire WE, Jacus MO, Salajegheh R, Jagodic MM, Choe W, Lee J, Lee SS, Rose KE, Poiro N, Digruccio MR, Krishnan K, Covey DF, Lee JH, Barrett PQ, Jevtovic-Todorovic $\mathrm{V}$, Todorovic SM. Reversal of neuropathic pain in diabetes by targeting glycosylation of $\mathrm{Ca}(\mathrm{V}) 3.2$ T-type calcium channels. Diabetes. 2013; 62:3828-38.

[51] Perez-Reyes E. Molecular physiology of low-voltage-activated T-type calcium channels. Physiol Rev. 2003; 83:117-61.

[52] Ross HR, Gilmore AJ, Connor M. Inhibition of human recombinant T-type calcium channels by the endocannabinoid $\mathrm{N}$-arachidonoyl dopamine. Br J Pharmacol. 2009; 156:740-50.

[53] Rzhepetskyy Y, Lazniewska J, Blesneac I, Pamphlett R, Weiss N. CACNA1H missense mutations associated with amyotrophic lateral sclerosis alter Cav3.2 T-type calcium channel activity and reticular thalamic neuron firing. Channels (Austin). 2016; 10:46677.

[54] Scholl UI, Stolting G, Nelson-Williams C, Vichot AA, Choi M, Loring E, Prasad ML, Goh G, Carling T, Juhlin CC, Quack I, Rump LC, Thiel A, Lande M, Frazier BG, Rasoulpour M, Bowlin DL, Sethna $\mathrm{CB}$, Trachtman $\mathrm{H}$, Fahlke $\mathrm{C}$, Lifton RP. Recurrent gain of function mutation in calcium channel CACNA1H causes early-onset hypertension with primary aldosteronism. Elife. 2015; 4:e06315.

[55] Splawski I, Timothy KW, Decher N, Kumar P, Sachse FB, Beggs AH, Sanguinetti MC, Keating MT. Severe arrhythmia disorder caused by cardiac L-type calcium channel mutations. Proc Natl Acad Sci U S A. 2005; 102:8089-96; discussion 8086-8.

[56] Splawski I, Timothy KW, Sharpe LM, Decher N, Kumar P, Bloise R, Napolitano C, Schwartz PJ, Joseph RM, Condouris K, TagerFlusberg H, Priori SG, Sanguinetti MC, Keating MT. Ca(V)1.2 calcium channel dysfunction causes a multisystem disorder including arrhythmia and autism. Cell. 2004; 119:19-31.

[57] Splawski I, Yoo DS, Stotz SC, Cherry A, Clapham DE, Keating MT. CACNA1H mutations in autism spectrum disorders. J Biol Chem. 2006; 281:22085-91.

[58] Steinberg KM, Yu B, Koboldt DC, Mardis ER, Pamphlett R. Exome sequencing of case-unaffected-parents trios reveals recessive 
and de novo genetic variants in sporadic ALS. Sci Rep. 2015; 5:9124.

[59] Todorovic SM, Jevtovic-Todorovic V. Neuropathic pain: role for presynaptic T-type channels in nociceptive signaling. Pflugers Arch. 2013; 465:921-7.

[60] Ufret-Vincenty CA, Baro DJ, Lederer WJ, Rockman HA, Quinones LE, Santana LF. Role of sodium channel deglycosylation in the genesis of cardiac arrhythmias in heart failure. J Biol Chem. 2001; 276:28197-203.

[61] Wang G, Bochorishvili G, Chen Y, Salvati KA, Zhang P, Dubel SJ, Perez-Reyes E, Snutch TP, Stornetta RL, Deisseroth K, Erisir A, Todorovic SM, Luo JH, Kapur J, Beenhakker MP, Zhu JJ. CaV3.2 calcium channels control NMDA receptor-mediated transmission: a new mechanism for absence epilepsy. Genes Dev. 2015; 29:1535-51.

[62] Watanabe I, Wang HG, Sutachan JJ, Zhu J, Recio-Pinto E, Thornhill WB. Glycosylation affects rat Kv1.1 potassium channel gating by a combined surface potential and cooperative subunit interaction mechanism. J Physiol. 2003; 550:51-66.

[63] Weiss N, Black SA, Bladen C, Chen L, Zamponi GW. Surface expression and function of Cav3.2 T-type calcium channels are controlled by asparagine-linked glycosylation. Pflugers Arch. 2013; 465:1159-70.

[64] Welsby PJ, Wang H, Wolfe JT, Colbran RJ, Johnson ML, Barrett $\mathrm{PQ}$. A mechanism for the direct regulation of T-type calcium channels by $\mathrm{Ca} 2+/$ calmodulin-dependent kinase II. J Neurosci. 2003; 23:10116-21.

[65] Yao J, Davies LA, Howard JD, Adney SK, Welsby PJ, Howell N, Carey $\mathrm{RM}$, Colbran RJ, Barrett PQ. Molecular basis for the modulation of native T-type $\mathrm{Ca} 2+$ channels in vivo by $\mathrm{Ca} 2+/$ calmodulindependent protein kinase II. J Clin Invest. 2006; 116:2403-12.

[66] Zamponi GW, Striessnig J, Koschak A, Dolphin AC. The Physiology, Pathology, and Pharmacology of Voltage-Gated Calcium Channels and Their Future Therapeutic Potential. Pharmacol Rev. 2015; 67:821-70.

[67] Zhang Y, Cribbs LL, Satin J. Arachidonic acid modulation of alpha1H, a cloned human T-type calcium channel. Am J Physiol Heart Circ Physiol. 2000; 278:H184-93.

[68] Zoghbi HY. Postnatal neurodevelopmental disorders: meeting at the synapse? Science. 2003; 302:826-30. 